\title{
Turning Risk into Opportunity Using Genomic Technologies in India
}

\author{
Mumtaz Baig* \\ Department of Zoology, Government Vidarbha Institute of Science and Humanities, India
}

*Corresponding author: Mumtaz Baig, Associate Professor and Group Head, Laboratory of Molecular and Conservation Genetics, Department of Zoology, Govt. Vidarbha Institute of Science and Humanities, Amravati-444604-India

Submission: 悳 September 26, 2017; Published: 眥 February 05, 2018

Keywords: K-Casein; Gwas; Genomics; Indigenous; SNP

\section{Opinion}

Today India is the second fastest economy in the world. Interestingly, India's growing economy is powered more by the boom of its information technology industries and less by the agriculture, despite of the fact that still $70 \%$ population in India lives in villages and depend on agriculture and agriculture related occupations such as animal husbandry. There are many local breeds of livestock especially cattle, sheep and chicken in India. In spite of availability of whole genomic information of cattle and chicken (Red jungle fowl) in public domain crossbreeding in indigenous breeds with exotic blood without utilizing the full potential of genomic information is going at unprecedented rate. According to the 19th livestock Census report 2012, there is marked increase in the crossbred livestock compare to local breeds in India. Most of the local indigenous breeds are classified as low producers and no serious efforts have been put into to improve them using well organised genome guided breeding program. What is most alarming is that some breeds are restricted to narrow breeding tracts and need immediate attention as they face the maximum pressure of their germplasm being diluted by the exotic breeds.

Creative Commons Attribution 4.0 International License

For possible submission use the below is the URL Submit Article
Over the years while working with cattle, our group has identified some novel SNP's and new alleles of kappa casein gene linked to milk production in local zebu cattle and communicated to Journal of dairy research. Aforementioned are the major issues related to indigenous livestock breeds in India. Also, when compare with US/Europe, India has smaller foot prints in biological research. To overcome the ongoing genetic erosion, I suggested following points viz.

i. Documentation of local breeds using genome wide associated technologies (gwas) by partnering/collaborating with nonveterinarian researchers interested in livestock genomics.

ii. Targeted and time bound research tie up with private sector related with agriculture and animal husbandry sector.

iii. Recruiting and supporting more researchers equipped with genomic technology in national labs and institutes linked with veterinary research.

\section{Your subsequent submission with Crimson Publishers} will attain the below benefits

- High-level peer review and editorial services

- Freely accessible online immediately upon publication

- Authors retain the copyright to their work

- Licensing it under a Creative Commons license

- Visibility through different online platforms

- Global attainment for your research

- Article availability in different formats (Pdf, E-pub, Full Text)

- Endless customer service

- Reasonable Membership services

- Reprints availability upon request

- One step article tracking system 